\title{
Identification and Detection of Maize Seed Borne Pathogens using Different Seed Testing Methods
}

\author{
B. Sreenu*, A. G. Girish and J. Alice R. P. Sujeetha \\ National Institute of Plant Health Management, Rajendranagar-500030, \\ Hyderabad, Telangana, India \\ *Corresponding author
}

Keywords

Maize, Aspergillus,

Rhizophus,

Fusarium,

Colletotrichum graminicola

Article Info

Accepted:

12 September 2019

Available Online:

10 October 2019

\section{A B S T R A C T}

Seeds/grains may have the risk of association of a pathogen while exporting. They are, therefore, routinely tested under phytosanitary regulations to prevent pathogens movement along with maize grains/seeds into new territories and also affect seed quality. As there is an increased demand for the export of maize from India and maize seed borne fungal pathogens are concern of phytosanitary regulations which are detected through the different seed health testing methods. Hence, maize seeds of Four varieties (DHM-121, DHM-117, BML-06 and local from chenevelly) tested for seed borne fungal mycoflora by blotter and agar plate method of seed testing as recommended by International Seed Testing Association (ISTA).The external seed borne pathogens were detected as Aspergillus flavus, A. niger, Fusarium moniliformae, Alternaria alternata and Curvularia lunata in both blotter and agar tests. Whereas internal seed borne pathogens were detected as Bipolaris maydis, Colletotrichum graminicola in agar plate method. Hence it is recommended that for the detection of Bipolaris maydis, Colletotrichum graminicola agar test methods are required.

\section{Introduction}

Maize (Zea mays L.) is one of the most important cereal crops in the world and ranks third next to wheat and rice (Aldrich et al., 1975). It accounts for around 10 per cent of total food grain production in the country. In India, it has a good potential as a cereal crop due to its low cost of production, wide adaptability and diversified use. The country has exported 7,05,513.8 MT of maize to Japan, Yemen Republic, Malaysia, Vietnam, Pakistan, Myanmar, Sri Lanka, Philippines and Bangladesh2017-18. There has been continuous demand to export of corn mainly due to increase in the demand of meat and starch sector and production of biofuel (Deepavali et al., 2013). The most important 
prerequisite for good crop production is the availability of good quality seeds of high yielding varieties, disease free, adapted to the growing area, and preference by the farmer. Fungi and all other types of pathogens that attack plants and cause a very serious economic impact on agricultural production due to their ability to induce diseases of cultivated crops that result in important yield losses (Paplomatas, 2006).

Seed-borne disease refers to the particular plant diseases that are transmitted by seed. Seed health is a well recognized factor in the modern agricultural science for desired plant population and good harvest (Rahman et al., 2008). Seedborne pathogens are a continuing problem and may even be responsible for the re-emergence of diseases of the past as well as the introduction of diseases into new areas (Walcott et al., 2007). Seed borne pathogens present a serious threat to seedling establishment (Walcott et al., 2003).The quality of planted seeds has a critical influence on the ability of crops to become established and to realize their full potential of yield and value (McGee, 1995).

Seed-borne fungi are one of the most important biotic constraints in seed production worldwide. They are responsible for both pre and post-emergence death of grains, affect seedling vigor, and thus cause some reduction in germination and also variation in plant morphology (Van Du et al., 2001; Rajput et al., 2005; Niaz and Dawar, 2009).

\section{Materials and Methods}

Threemaize varieties DHM-121, DHM-117, BML-06 were collected from Maize Research station, Hyderabad and one local variety from village Chenevelly, Mandal Chevella, District Rangareddy for the study. Following seed health testing methods were used for the detection of seed borne fungal pathogens.

\section{Visual examination}

Maize seeds that have visible blue, white, green and pink mycelial growth on its tip or surface of seed. These symptoms are due to the infection of Fusarium, Diplodia, Penicillium Green Mould symptom is especially due to Aspergillus flavus. All varieties seed samples were inspected for these symptoms under magnoscope.

\section{Blotter test}

All Four maize varieties seeds were analyzed for the presence of major seed borne fungal pathogens by blotter method following the International Seed Testing Association [ISTA, 1996]. Total hundred seeds without surface sterilized were tested for each variety. Ten seeds were placed on three layers of moist blotting paper in each petridish. The petridishes were incubated at $25 \pm 1{ }^{\circ} \mathrm{C}$ under $12 / 12 \mathrm{hrs}$ light and darkness cycle for 7 days. Each seed was observed under stereomicroscope in order to record the presence of fungal colony and temporary slides were prepared from the fungal colony for observation under compound microscope.

Keys (Malone et al., 1964 and Misra et al., 1994) were consulted for identification of the fungi. The results were presented as percent incidence for individual pathogen. Germination of the seeds was also recorded.

Each individual incubated seed was observed under stereomicroscope at 10x, 40x magnification in order to record the incidence of seed borne fungi.

Most of the associated pathogens were detected by observing their growth characters on the incubated seeds on blotter paper following the keys outlined by (Mathur and Kongsdal, 2003), Ellis, 1971; Chidambaram and Mathur, 1975 and Neergaard and Saad, 
1962. [Booth; 1971 and Agarwal et al., 1990]and with the help of different books, manuals and publications. The results were presented as percent incidence for individual pathogen.

Temporary semi permanent slides were prepared from the fungal colony and observed under compound microscope for use as future reference and for the stockholders.

\section{Agar Plate Method}

In the agar plate method, a total hundred seeds were tested. Seed were surface disinfected with 3\% Sodium hypochlorite and then plated (10 seeds/plate) on the petridish containing agar medium (3\%).

All plated seeds were then incubated for 5-7 days at $22-25^{\circ} \mathrm{C}$ under $12 \mathrm{~h}$ altering cycles of light and darkness. At the end of the incubation period, fungi growing out from the seeds on the agar medium were examined and identified. Identification was done based on colony characters and morphology of sporulation structures under a compound microscope.

Thereafter, the identification of the different colonies were done visually and then under a stereomicroscope and followed by an examination of the fruiting structures under a compound microscope. Once the identification was done, the colonies were assigned names and their acronyms written on the reverse (Mathur and Kongsdal, 2003).

\section{Results and Discussion}

Among the four varieties (including one local) tested, varietyBML-06 was found with less seed borne infection in blotter as well as in agar test. All fungal pathogen infection was also found less BML-06 compared to other varieties.

\section{Visual Examination}

Hundred seeds from each varieties observed under Magnoscope having $10 \mathrm{X}$ magnification.

The seeds were observed for pink, white and green discoloration for the detection of Diplodia spp, and Penicillium spp, respectively. No visual symptoms were noticed in these pathogens.

Hence following seed health testing methods were also conducted to detect hidden infection of seed borne pathogens.

\section{Blotter test}

Hundred seeds of each variety (10 seeds per plate) used for blotter method. Five fungal flora Aspergillus flavus, Aspergillus niger, Fusarium moniliformae, Curvularia lunata and Alternaria alternata were detected under stereo binocular microscope based on colony morphology and these were further identified under the compound microscope based on spore/conidial morphological studies.

The highest incidence of Aspergillus flavus was noticed in local variety $(53 \%)$ where as lowest infection in BML-06 (30 \%). Highest infection Aspergillus niger was noticed on DHM-121 (60 \%) and lowest infection on BML-06 (30 \%). Fusarium moniliformae showed highest infection on DHM-121 (60 \%) and lowest on BML-06 (33\%). Curvularia lunata highest infection detected on local variety andDHM-121 (both26\%) and lowest infection on BML-06 (13\%). Highest infection of Alternaria alternata noticed on local variety $(50 \%)$ and lowest infection on DHM-117 (36 \%) (Table 1). Blotter test conducted for local variety showing grayish colony growth of Alternaria alternata and white colony growth of Fusarium moniliformae after 7 days shown in Figure 1. 
Table.1 Percent (\%) incidence of different seed borne pathogens recorded in maize in blotter method

\begin{tabular}{|c|c|c|c|c|c|}
\hline Maize varieties & $\begin{array}{c}\text { Aspergillus } \\
\text { flavus }\end{array}$ & $\begin{array}{c}\text { Aspergillus } \\
\text { niger }\end{array}$ & $\begin{array}{c}\text { Fusarium } \\
\text { moniliformae }\end{array}$ & $\begin{array}{c}\text { Curvularia } \\
\text { lunata }\end{array}$ & $\begin{array}{c}\text { Alternaria } \\
\text { alternata }\end{array}$ \\
\hline DHM-121 & 46 & 60 & 60 & 26 & 46 \\
\hline DHM-117 & 36 & 56 & 56 & 20 & 36 \\
\hline BML-06 & 30 & 36 & 33 & 13 & 43 \\
\hline Local variety & 53 & 43 & 50 & 26 & 50 \\
\hline
\end{tabular}

Table.2 Per cent (\%) incidence of different seed borne pathogens recorded in maize in agar method

\begin{tabular}{|c|c|c|c|c|c|}
\hline Maize varieties & $\begin{array}{c}\text { Fusarium } \\
\text { moniliformae }\end{array}$ & $\begin{array}{c}\text { Colletotrichum } \\
\text { graminicola }\end{array}$ & $\begin{array}{c}\text { Curvularia } \\
\text { lunata }\end{array}$ & $\begin{array}{c}\text { Bipolarisma } \\
\text { ydis }\end{array}$ & $\begin{array}{c}\text { Alternaria } \\
\text { alternata }\end{array}$ \\
\hline DHM-121 & 40 & 43 & 46 & 26 & 53 \\
\hline DHM-117 & 36 & 40 & 40 & 26 & 53 \\
\hline BML-06 & 33 & 23 & 33 & 23 & 46 \\
\hline Local variety & 53 & 43 & 46 & 30 & 50 \\
\hline
\end{tabular}

Fig.1 Blotter test of local variety showing:1. Day one seeds on blotter 2.Alternaria alternate colony growth after 7 days 3.Fusarium moniliformae colony growth after 7 days.

\section{Blotter test Stereo binocular photographs at $10 \mathrm{X}$}
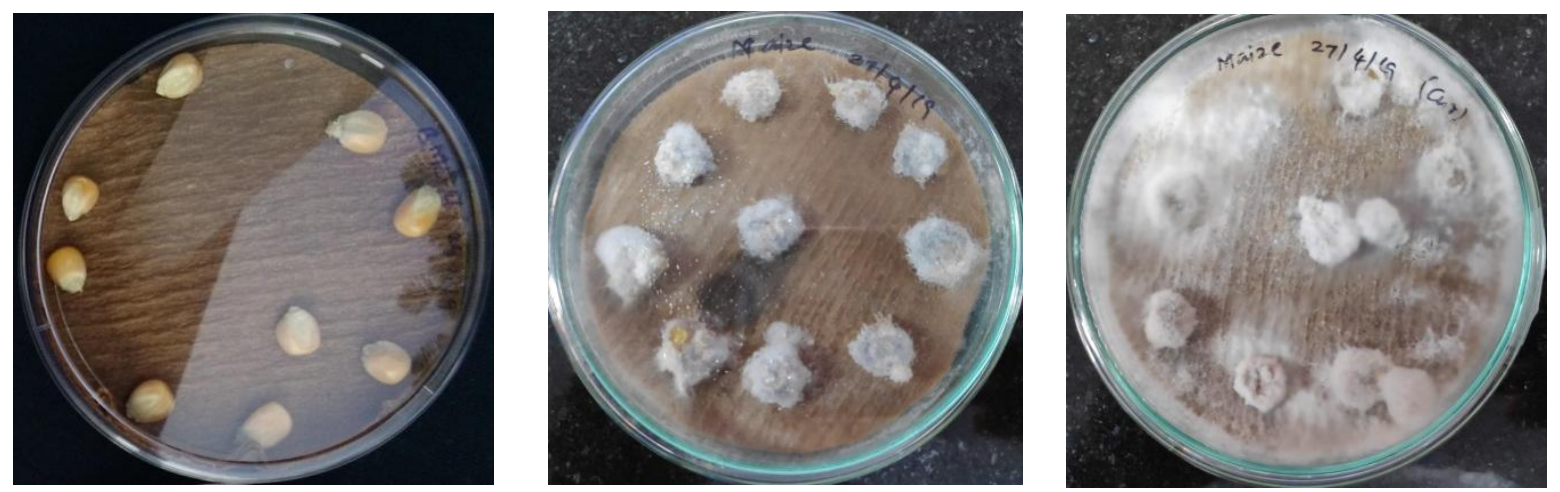

Fig.2 Agar test of local variety showing: 1. Day one seeds on agar 2. Alternaria alternata colony growth after 7 days 3. Fusarium moniliformae colony growth after 7 days 4. Curvularia lunata colony growth after 7 days; 5.Bipolarismaydiscolony growth after 7 days

Agar test Stereo binocular photographs at $10 \mathrm{X}$
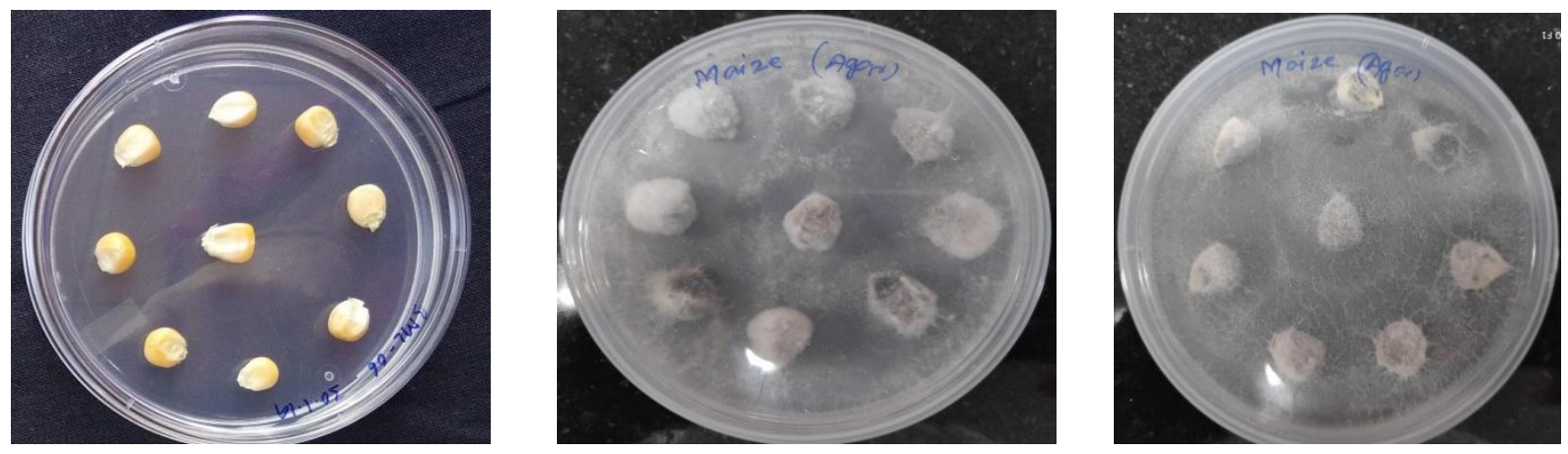
Fig.3 Colony and spore/conidial structures under the compound microscope

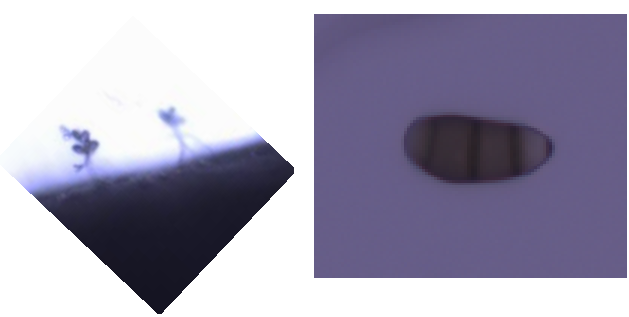

Curvularia lunata
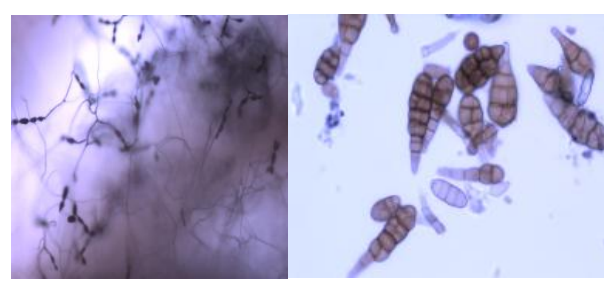

Alternaria alternata

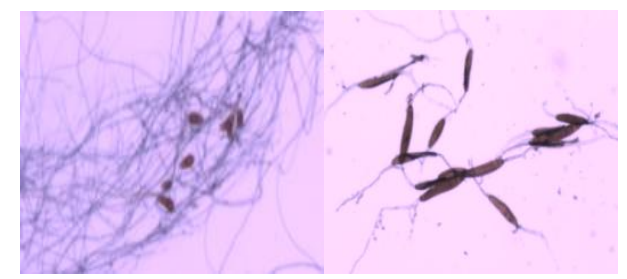

Bipolaris maydis
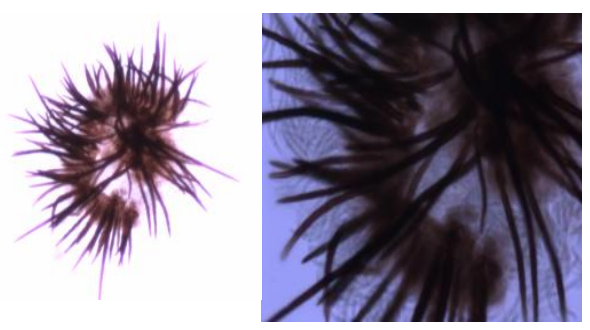

Colletotrichum graminicola,

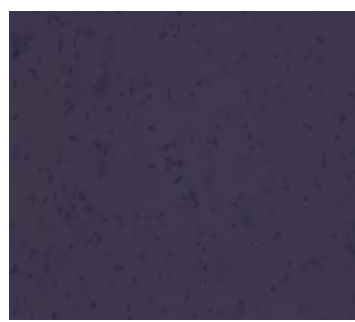

Fusarium moniliformae

\section{Agar test}

In Agar plate method, five seed borne pathogens were detected and identified. They are Bipolaris maydis, Curvularia lunata, Colletotrichum graminicola, Fusarium moniliformae and Alternaria alternata. Fusarium moniliformae showed highest infection on local variety (53\%) and lowest infection on BML-06 (33\%). Curvularia lunata highest infection detected on local variety and DHM-121 (both $46 \%$ ) and lowest infection on BML-06 (33\%). Alternaria alternate noticed highest infection on DHM$121(53 \%)$ and lowest infection on BML-06 (46\%).

Colletotrichum graminicola showed highest infection on local variety and DHM-121 (43 $\%)$ and lowest infection on BML-06 (23\%). Highest infection of Bipolarismaydis noticed on local variety $(30 \%)$ and lowest infection on BML-06 (23 \%) (Table 2). Colony growth Alternaria alternata, Curvularia lunata, Fusarium moniliformae, Bipolarismaydis and Colletotrichum graminicola shown on local variety in Agar test (Fig. 2).
Alternaria alternata, Curvularia lunata, Fusarium moniliformae, Bipolarismaydis and Colletotrichum graminicola colony and spore/conidial structures under the compound microscope shown in Figure 3.

Even though the visual symptoms not appeared on the seeds of all tested varieties, seed borne pathogens were detected and identified under the blotter and agar test. Colletotrichum graminicola and Bipolarismaydis appears in only agar and not in blotter as aspergillus spp are external seed borne infection and might have hinder the growth of Bipolarismaydisand Colletotrichum graminicolaspecies as both are slow growing where as Aspergillus flavus species are fast growing. In agar the Aspergillus flavus species infection may be suppressed the growth of the Aspergillus flavus species due to surface sterilization of seed. In the laboratory studies, Bipolaris maydis is reported to be an important seedborne fungus of maize. But fortunately the incidence of $B$. maydis was the lowest among the fungi detected in the present investigation. This might be due to Bipolaris 
free seeds used by the farmers, lower inoculum potential and lower infection of the crop in the farmers' fields. The present findings of the seedborne fungal organisms were in agreement with the information of seedborne nature of the pathogen reported by Sitara and Akhter (2007), Khan (2006), Islam (2005), Owolade et al., (2002), Tanaka et al., (2001), Fakir (2001), White (1999), Goulart (1993) and Bujari et al., (1993). The result of the present study reveals that Alternaria alternata, Curvularia lunata, Fusarium moniliformae, Bipolarismaydis and Colletotrichum graminicola were detected and identified as seed borne fungal flora. BML -06 variety shown less infected among the others tested maize seed varieties. Pathogen free seed is the vital input in agriculture. Most of the varieties seeds/grains are exported from India and are tested under the phytosanitary regulations. Generally the visual and blotter tests are routinely carried out during the phytosanitary regulations. Present study revealed that seed microflora some pathogens were recorded only in agar test and blotter test. As pathogen free seed is an important component under trade hence the present study will help in carrying out the agar test along with blotter test.

\section{Acknowledgement}

The authors are greatly acknowledged to the Director General, NIPHM for the support of research. The authors also acknowledge to Maize Research Station, PJTSAU, Rajendranagar, Hyderabad for providing seed materials to carry out the research.

\section{References}

Agarwal, P.C., C.N. Mortensen and S.B. Mathur, 1990. Seed borne disease and seed health testing of rice. Journal of Agriculture Science, Cambridge., 115, 144-144.
Aldrich SR, Scott WO, Leng ER. 1975. Modern corn production. 2nd edition. United States of America pp. 1-5.

Bujari J, Ershad D. 1993.An investigation on corn seed mycoflora. Iranian Journal of Plant Pathology 29(1-2), 13-17.

Booth, C. 1971. The genus Fusarium.CMI, Kew, Surrey, England.237 pp.

Chidambaram, P.S. and S.B. Mathur, 1975. Deterioration of grains by fungi. Ann. Rev. Phytopathol., 3: 69-89.

Deepavali S, and Nilima WK. 2013. Incidence of Seedborne Mycoflora on Maize and its effect on seed germination, Int. J. of Current Research, 5(12), pp.41514155.

Ellis, M.B. 1971. Demotiaceous Hyphomycetes. C.M.I., Kew Surrey England, 608 pp.

Fakir GA. 2001. List of seed borne diseases of important crops occurring in Bangladesh. Seed Pathol. Lab., Dept. Pl. Pathol., Bangladesh Agricultural University, Mymensingh 9p.

Goulart ACP. 1993. Treatment of maize (Zea mays L.) seeds with fungicides. Revista Brasileira de Sementes 15(2), 165-169.

International seed testing authorituy, 1991.

Islam MH. 2005. Prevalence and pathogenicity of fungi in maize seeds. An MS thesis submitted to the Department of Plant Pathology, Bangladesh Agricultural University, Mymensingh $17 \mathrm{p}$.

Khan MMR. 2006. Effects of Fungicides in Controlling Fungal Flora of Corn Seeds. An MS thesis submitted to the Department of Plant Pathology, Bangladesh Agricultural University, Mymensingh. Pp. 34-36.

Malone, G.P. and A.E. Muskette, 1964. Seed borne fungi: Description of 77 Fungal Species. Proc. Int. Seed Test Assoc., 29(2): 180-183.

Mathur, S.B. and O. Kongsdal, 2003.Common 
laboratory seed health testing method for detecting fungi.First edition. International Seed Testing.

Mathur, S. B. and Neergaard, P. (1971). Serodiagnosis of tobacco mosaic virus in tomato seed. 2nd International Symposium 011 Plant Pathology, New Delhi (Abstr.).

McGee D.C., 1995. Approach to disease management through seed technology. Annu. Rev. Phytopathol. 1995.33:445466.

Misra, J.K. Gergon and T.W. Mew, 1994. Occurrence, distribution and phenology of seed borne fungi of rice in certain provinces of Philippine. Plant Pathol. Bull., 3(4): 229-239.

Neergaard, P. and A. Saad, 1962.Seed health testing of rice: A contribution to development of laboratory routine testing methods. Indian Phytopathol. 15: 85-111.

Niaz I. and Dawar S., 2009.Detection of seed borne mycoflora in maize (Zea mays L.). Pak. J. Bot. 41(1): 443- 451.

Owolade OF, Fawole B, Osikanlu UOK. 2002. Evaluation of seed health testing methods for seed borne fungi of maize. Institute of Agricultural Research and Training, Moor Plantation, Ibadan, Nigeria. Moor Journal of Agricultural Research 3(2), 385-286.

Paplomatas E.J., 2006. Molecular diagnostics of fungal pathogens. Arab J. Pl. Prot. 24: 147-158.

Rajput MA, Pathan MA, Lodhi AM, Shah GS,
Khanzada KA (2005). Studies on seedborne fungi of wheat in Sindh Province and their effect on seed germination. Pak. J. Bot. 37(1): 181-185.

Rahman M.M.E., Ali M.E., Ali M.S., Rahman M.M. and Islam M. N., 2008.Hot Water Thermal Treatment for Controlling Seed-Borne Mycoflora of Maize. Int. J. Sustain. Crop Prod. 3(5): 5-9.

Sitara U, Akhter S. 2007. Efficacy of fungicides, Sodium hypochlorite and neem seed powder to control seed borne pathogen of maize. Karachi University Campus, Karachi-75270, Pakistan. Pac. J. Bot 39(1), 285-292.

Tanaka M, Maeda JA, Plazas I. 2001. Fungi associated to corn seed under storage conditions. Centro de Fitossanidade, Campinas, SP, Brazil. Scientia Agricola 58(3), 501-508.

Van Du P, Loan LC, Cuong ND, Nghiep HV, Thach ND (2001). Survey on seed borne fungi and its effects on grain quality of common rice cultivars in the Mekong Delta.Omonrice, 9: 107-113.

Walcott RR, Gitaitis RD, Castro AC. 2003. Role of blossoms in watermelon seed infestation by Acidovoraxavenae subsp. citrulli.Phytopathol. 93:528-34.

Walcott RR. 2003. Detection of seedborne pathogens. HortTechnology 13:40-47.

White DG. 1999. Compendium of Corn Diseases. APS Press. The American Phytopathological Society.3 rd edition. Pp. 1-54.

\section{How to cite this article:}

Sreenu, B., A. G. Girish and J. Alice R. P. Sujeetha. 2019. Identification and Detection of Maize Seed Borne Pathogens using Different Seed Testing Methods. Int.J.Curr.Microbiol.App.Sci. 8(10): 1460-1466. doi: https://doi.org/10.20546/ijcmas.2019.810.171 